\title{
Precise chitinozoan dating of Ordovician impact events in Baltoscandia
}

\author{
YNGVE GRAHN ${ }^{\prime}$, JAAK NÕLVAK ${ }^{2} \&$ FLORENTIN PARIS ${ }^{3}$ \\ ${ }^{1}$ Swedish Museum of Natural History, Department of Palaeozoology, Box 50007, S-10405 Stockholm, Sweden \\ ${ }^{2}$ Estonian Academy of Sciences, Institute of Geology, 7 Estonia Avenue, EE-0105 Tallinn, Estonia \\ ${ }^{3}$ Université de Rennes, Laboratoire de Paléontologie et Stratigraphie, URA 1364 du CNRS, Avenue du Général Leclerc, \\ F-35042 Rennes Cedex, France
}

\begin{abstract}
The chitinozoan biostratigraphy of four Ordovician impact craters has been investigated. Three of these (Tvären, Kärdla and Lockne) contain complete sequences of early Caradoc age, while the Granby crater contains rocks of late Arenig age yielding two bentonitic horizons at their top. Chitinozoans, together with graptolites and other planktic organisms, were the first to invade the craters after the impact event. It has therefore been possible to date the impact events with a precision of less than one million years. An immigration of graptolites from Australia during the late Arenig corresponds to an immigration of chitinozoans from Gondwana at this time. Two stratigraphically important taxa, not previously described or discussed, Lagenochitina sp. A aff. capax and Laufeldochitina sp. A aff. striata are commented upon. Three species, Cyathochitina hunderumensis, Spinachitina tvaerenensis and Tanuchitina granbyensis, are described as new. I. Micropalaeontol. 15(1): 21-35. April 1996.
\end{abstract}

\section{INTRODUCTION}

Five impact events of supposed Ordovician age have been reported from Baltoscandia (see Henkel \& Pesonen, 1992). Four of these were recently dated by Grahn \& Nõlvak (1993). A crater below the bottom of the Lumparen Bay in the Aland archipelago, between Sweden and the mainland of Finland, was for a long time considered to be of tectonic origin (see Winterhalter 1982), but Merrill (1980) regarded it to be an Ordovician or younger impact structure. More recent investigations show that the Lumparen Bay structure probably is an impact crater that was already deeply eroded when Ordovician sedimentation commenced in the area during the early Arenig. The Lumparen event might be of early Cambrian age since sandstones of this age, reminiscent of resurge deposits, are distributed in the area (Hagenfeldt, pers. comm. 1993). The oldest Ordovician crater, of late Arenig age, is situated at Granby in south Sweden (Fig. 1). The three other craters, of early Caradoc age, occur at Tvären and Lockne in central Sweden, and at Kärdla on the Island of Hiiumaa in northwest Estonia (Fig. 1).

The maximum thickness of the Ordovician sequences outside the craters is less than $200 \mathrm{~m}$ in Sweden and Estonia, and stratigraphical gaps occur frequently through the sequence. In contrast to the sequences surrounding the craters, those within the craters are virtually complete. The crater sequences are therefore excellent models for ecological studies of restricted environments and for high-resolution biostratigraphy. The present paper is a detailed study of the chitinozoan biostratigraphy in the four Ordovician craters investigated. The illustrated specimens are deposited in the collections of the Institute of Geology, Rennes (IGR) under the numbers 58601-58646. The coordinates are those of the England Finder grid.

\section{CHITINOZOAN BIOSTRATIGRAPHY}

Nőlvak \& Grahn (1993) recently published a chitinozoan biozonation comprising 23 zones and subzones for the
Ordovician of Baltoscandia. All eight crater sections investigated from or close to the four craters yielded the index species and/or characteristic species for three of these zones, which allowed a very precise dating. The biostratigraphy from the sections related to the four craters will be described below.

\section{Granby crater}

The Granby crater is situated in the subsurface about $4 \mathrm{~km}$ southeast of Vadstena, a little town on the east shore of Lake Vättern. It has been discussed by Bruun \& Dahlman (1982) and Grahn \& Nōlvak (1993). Two cores from the crater were investigated, viz. from the Fylla 9 borehole about $1 \mathrm{~km}$ east of the west crater rim, and the Fylla 3 borehole, about $800 \mathrm{~m}$ further to the east (Fig. 2). The latter borehole was made near the centre of the crater above the central uplift (Bruun \& Dahlman, 1982). The impact sediments in the crater are overlain by calcareous and glauconitic mudstone interbedded by grey limestone. The impact event is placed in the lower part of the Cyathochitina regnelli chitinozoan Zone, since a characteristic chitinozoan assemblage from the Conochitina cucumis chitinozoan Zone is missing (Nôlvak \& Grahn 1993). The index fossil has not been found (Grahn \& Nôlvak, 1993), but the presence of for instance Conochitina decipiens (Pl. 1, figs 8,9$)$ together with Cyathochitina hunderumensis sp. nov. (see Systematic Desciptions; Figs 3, 4; Pl. 1, figs 1, 10, 11) and Tanuchitina granbyensis sp. nov. (see Systematic Descriptions; Figs 3, 4; Pl. 1. figs 2-5) suggests a late Arenig age. In the crater sequence occur also, among others, Rhabdochitina gracilis (Pl. 3, fig. 8), Conochitina sp. 1 (Pl. 3, fig. 5) and Lagenochitina esthonica (Pl. 3, fig. 9). Two bentonitic horizons found in the Fylla 9 core (Fig. 3) are probably of the same age, as evidenced from the presence in these levels by Clavachitina poumoti ( $\mathrm{Pl}$. 1, figs 6,7), a species reported from Upper Arenig strata in Australia (Combaz \& Peniguel, 


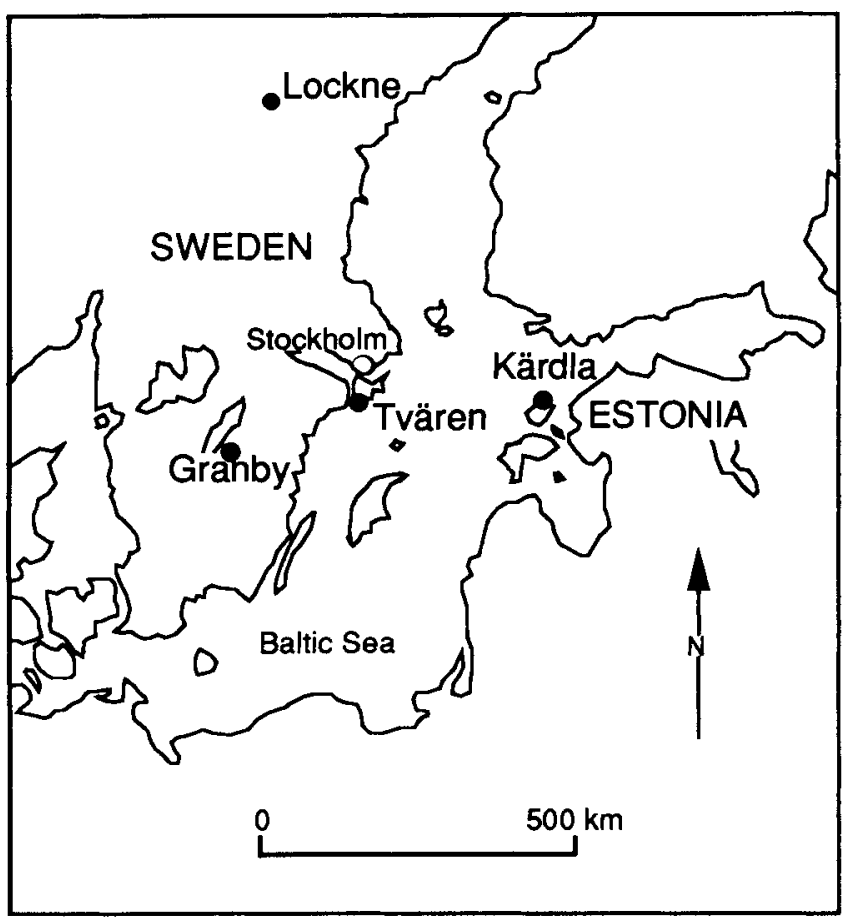

Fig. 1. Map showing the sites of the investigated Ordovician impact craters in Baltoscandia.

1972), Svalbard (Bockelie 1980) and eastern Canada (Achab, 1986). It should be noted that in the graptolite Zone of Didymograptus hirundo (late Arenig) there is also evidence of an immigration of graptolites from Australia into Baltoscandia (Nilsson, 1983).

\section{Tvären crater}

The Tvären crater is situated below the bottom of the Tvären Bay, about $72 \mathrm{~km}$ south-southwest of Stockholm. It has been discussed by Flodén et al. (1986) and Lindström et al. (1994). Two boreholes, Tvären 1 and 2, were drilled in the structure (Fig. 5). The former borehole was placed in the crater rim, while the latter (Fig. 6) penetrated the whole sedimentary sequence ending in the basement breccia. In the first post-impact sediments, consisting of dark grey calcareous mudstone with interbedded limestone, the index

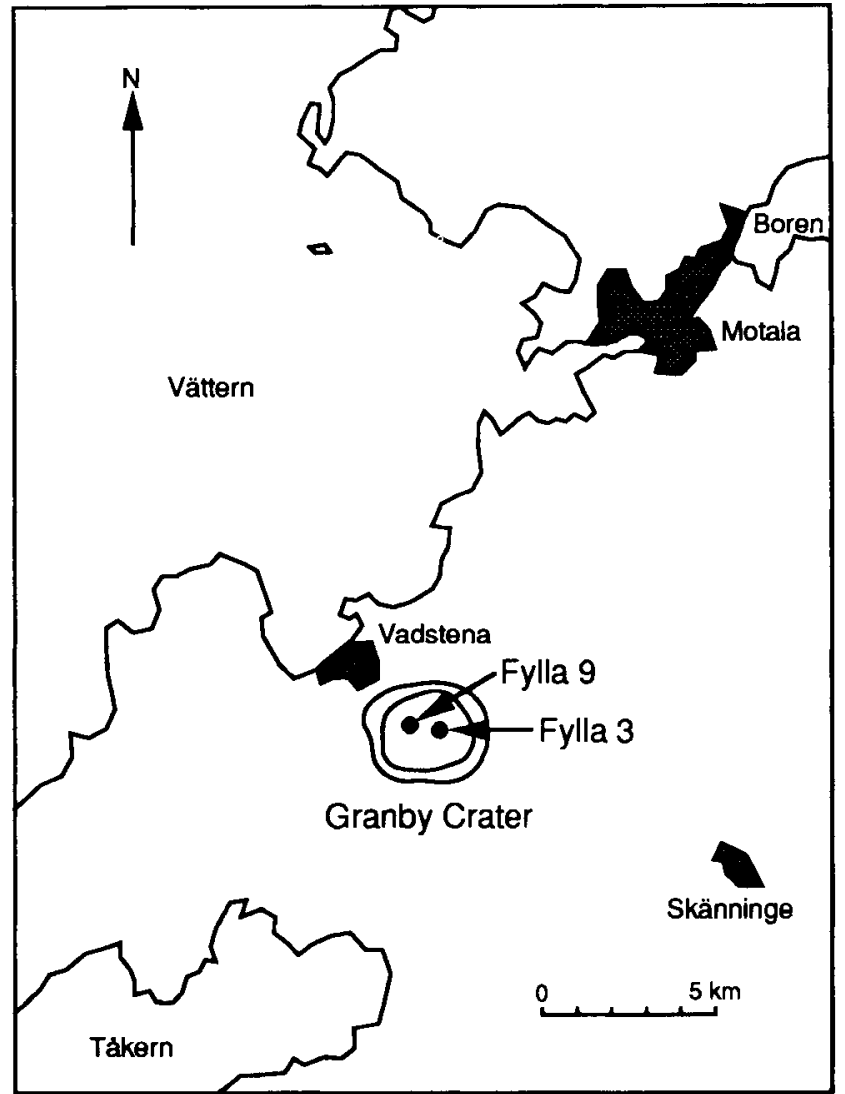

Fig. 2. Map showing the sites of the investigated boreholes in the Granby crater, Östergötland, Sweden.

species Laufeldochitina stentor (Pl. 2, fig. 6) occur together with Lagenochitina sp. A aff. capax (Pl. 3, figs. 1, 2) and Laufeldochitina sp. A aff. striata (Pl. 2, figs 9, 10). The presence of $L$. sp. A aff. striata is characteristic for a short interval in the upper part of the L. stentor Zone, where the index species is rare or absent (Nolvak \& Grahn, 1993). Laufeldochitina sp. A aff. striata was also found in a coarse breccia formed by the resurge turbidite immediately after the impact. This places the base of the Tvären post-impact sequence, and the impact event, within beds corresponding to the lower Peetri Member of the Viivikonna Formation

\section{Explanation of Plate 1}

Selected chitinozoans from the Granby crater. Late Arenig. Fig. 1. Cyathochitina hunderumensis sp. nov. Holotype. Fylla 3 borehole, core sample at $254.30 \mathrm{~m}$. Specimen in lateral view, SEM $\times 300$. IGR 58614 (L. 39/4). Fig. 2. Tanuchitina granbyensis sp. nov. Holotype. Fylla 9 borehole, core sample at $272.20 \mathrm{~m}$. Specimen in lateral view, SEM $\times 75$. IGR 58601 (O. 43). Fig. 3. Tanuchitina granbyensis sp. nov. Holotype. Fylla 9 borehole, core sample at $272.20 \mathrm{~m}$. Detail of the base showing the carina, SEM $\times 500$. Fig. 4. Tanuchitina granbyensis sp. nov. Fylla 9 borehole, core sample at $270.20 \mathrm{~m}$. Specimen in lateral view, SEM $\times 75$. IGR 58601 (O. 40/1). Fig. 5. Tanuchitina granbyensis sp. nov. Same species as in fig. 4. Detail of the base showing the broken carina, SEM $\times 500$. Fig. 6. Clavachitina poumoti (Combaz \& Peniguel 1972). Fylla 9 borehole, core sample at $199.35 \mathrm{~m}$. Specimen in lateral view, SEM $\times 150$. IGR 58607 (O. 34/2). Fig. 7. Clavachitina poumoti (Combaz \& Peniguel, 1972). Fylla 9 borehole, core sample at $199.35 \mathrm{~m}$. Specimen in lateral view, SEM $\times 100$. IGR 58607 (R. 36). Fig. 8. Conochitina decipiens Taugourdeau \& Jekhowsky, 1960. Fylla 3 borehole, core sample at $254.30 \mathrm{~m}$. Specimen in lateral view, SEM $\times 300$. IGR 58614 (N. 36). Fig. 9. Conochitina decipiens Taugourdeau \& Jekhowsky, 1960. Fylla 9 borehole, core sample at $228.10 \mathrm{~m}$. Specimen in lateral view, SEM $\times 200$. IGR 58604 (Q. 41/2). Fig. 10. Cyathochitina hunderumensis sp. nov. Fylla 9 borehole, core sample at $265.30 \mathrm{~m}$. Specimen in lateral view, SEM $\times 300$. IGR 58604 (Q. 37/1). Fig. 11. Cyathochitina hunderumensis sp. nov. Fylla 9 borehole, core sample at $265.30 \mathrm{~m}$. Specimen in lateral view, SEM $\times 300$. IGR 58604 (P. 37/3). 

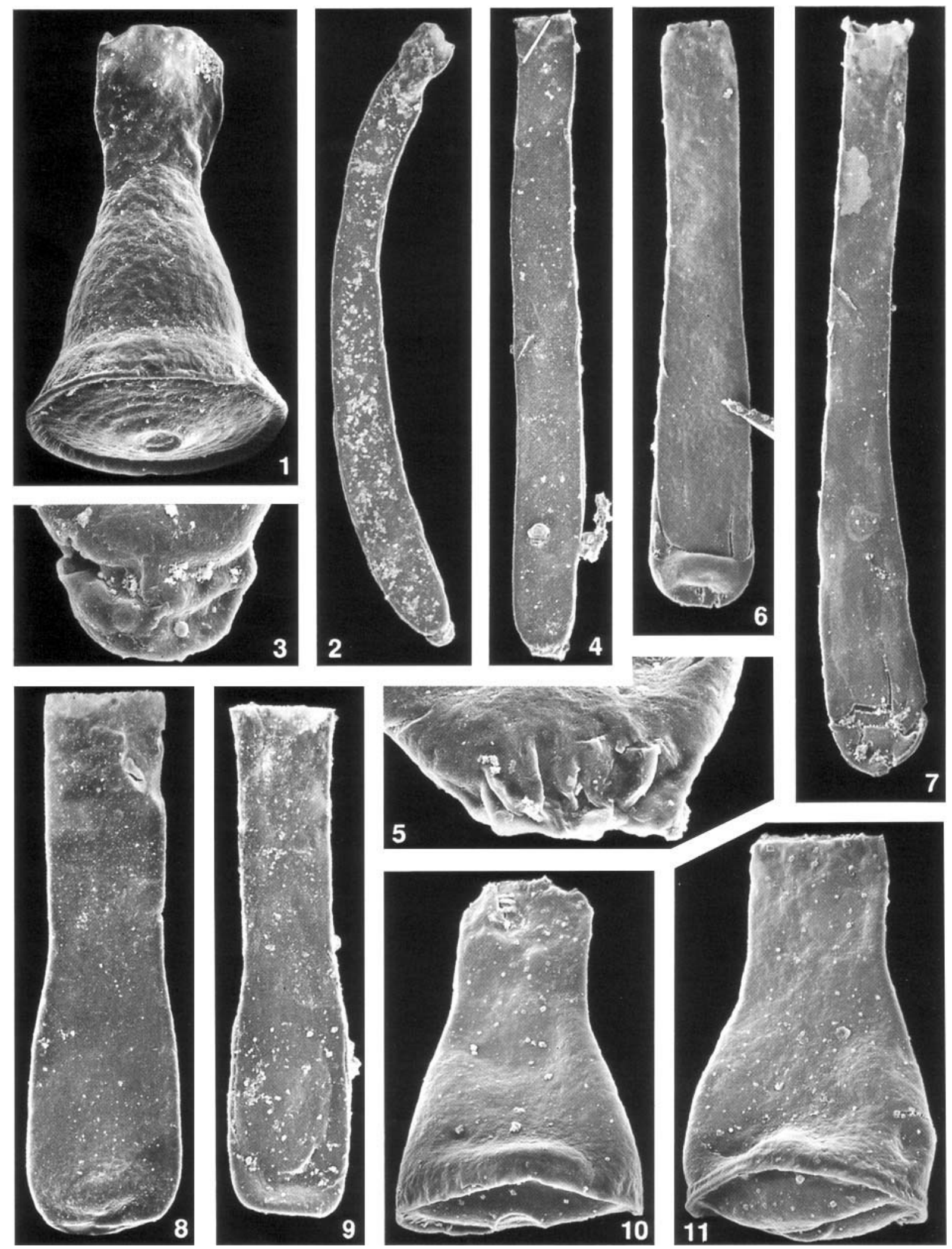

7

Plate 1 
FYLLA 9
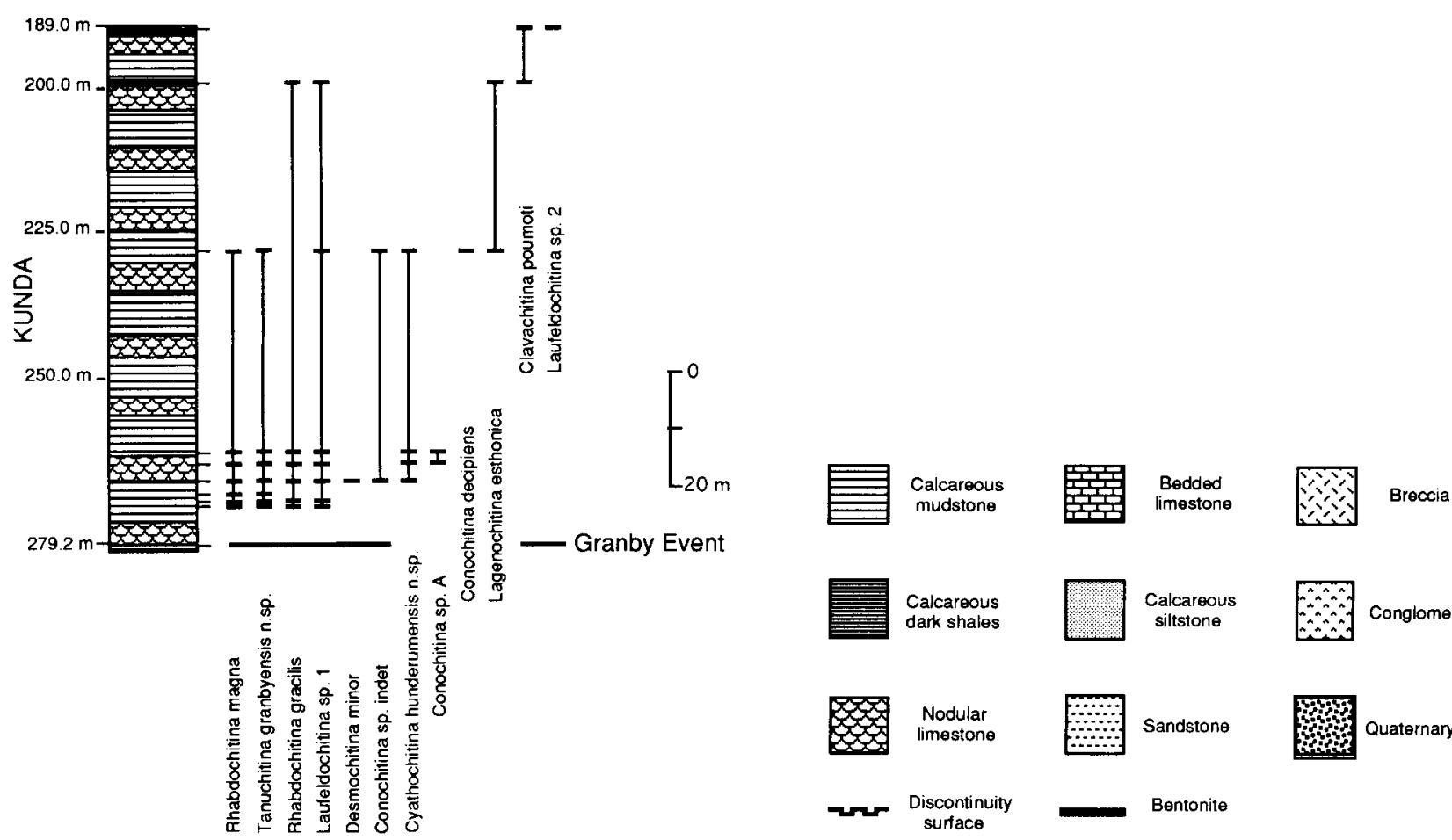

Calcareous dark shales

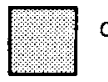

Calcareous siltstone

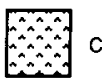
Conglomerate

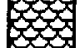

Nodular
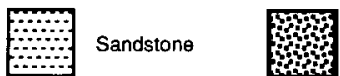

Quaternary deposits

Fig. 3. Faunal log of the Fylla 9 borehole, Granby crater, with sedimentary legend.

(Kukruse Stage) in North Estonia (Figs 6, 14). An important taxon L. sp. A aff. capax (ranging from upper Kukruse to lower Idavere; Nõlvak, unpublished data), is also confirming an early Caradoc age (Fig. 14). Other common species are Conochitina minnesotensis (Pl. 3, fig. 7), Calpichitina complanata, Calpichitina lecaniella (Pl. 2, figs 3, 5), Cyathochitina kuckersiana and Desmochitina ovulum. In the topmost layer of the pre-Quaternary rocks in the Tvären 2

\section{FYLLA 3}

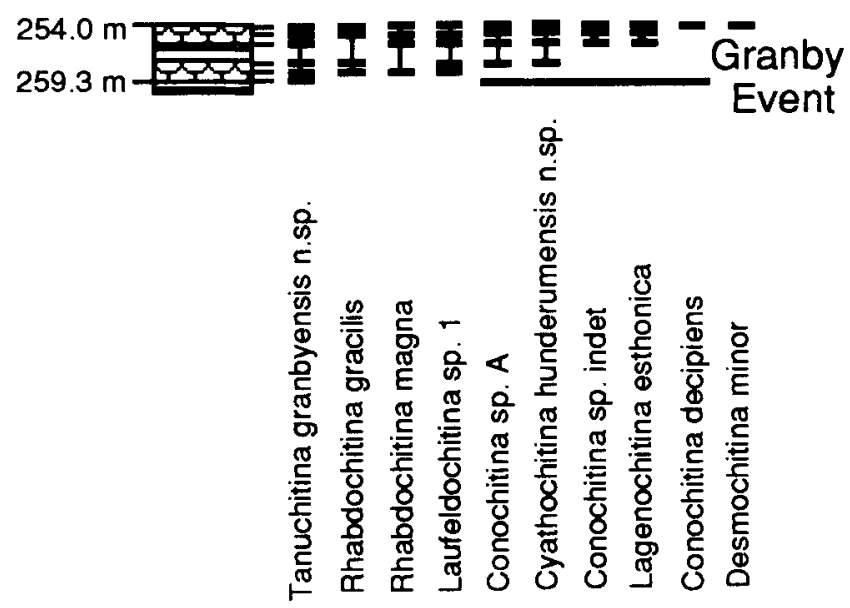

Fig. 4. Faunal $\log$ of the Fylla 3 borehole, Granby crater. borehole Conochitina tigrina (Pl. 2, figs 1, 2, Pl. 3, fig. 4) occurs with Spinachitina tvaerenensis sp. nov. (see Systematic Descriptions; Fig. 6; Pl. 2, figs 4, 7, 8, Pl. 3, fig. 6, 11). These species appear in a short interval at the top of the Kukruse Stage in Baltoscandia.

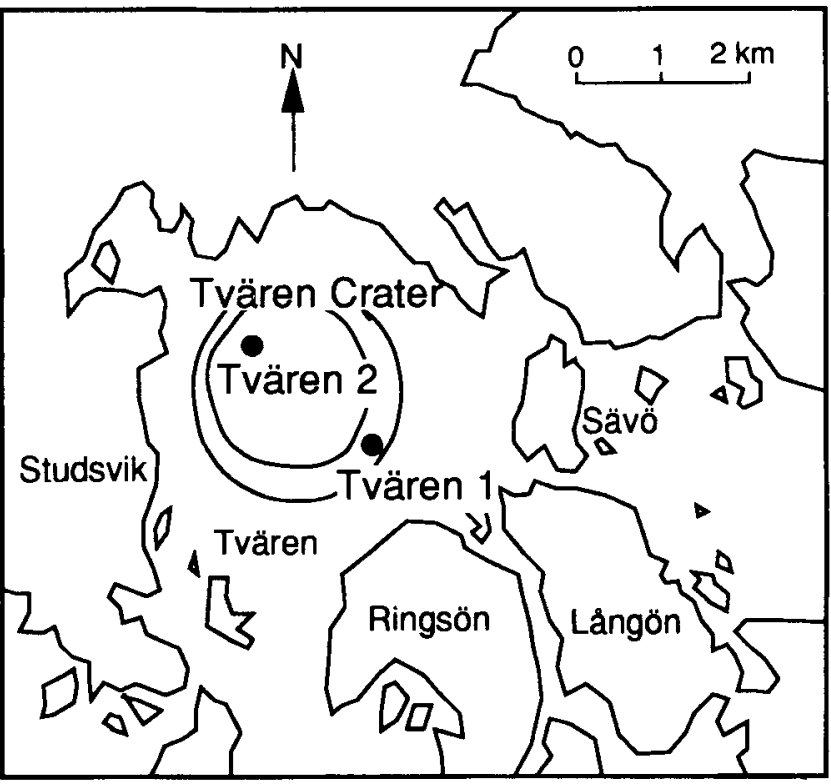

Fig. 5. Map showing the site of the Tvären 1 and 2 boreholes in the Tvären crater, Södermanland, Sweden. 
TVÄREN 2

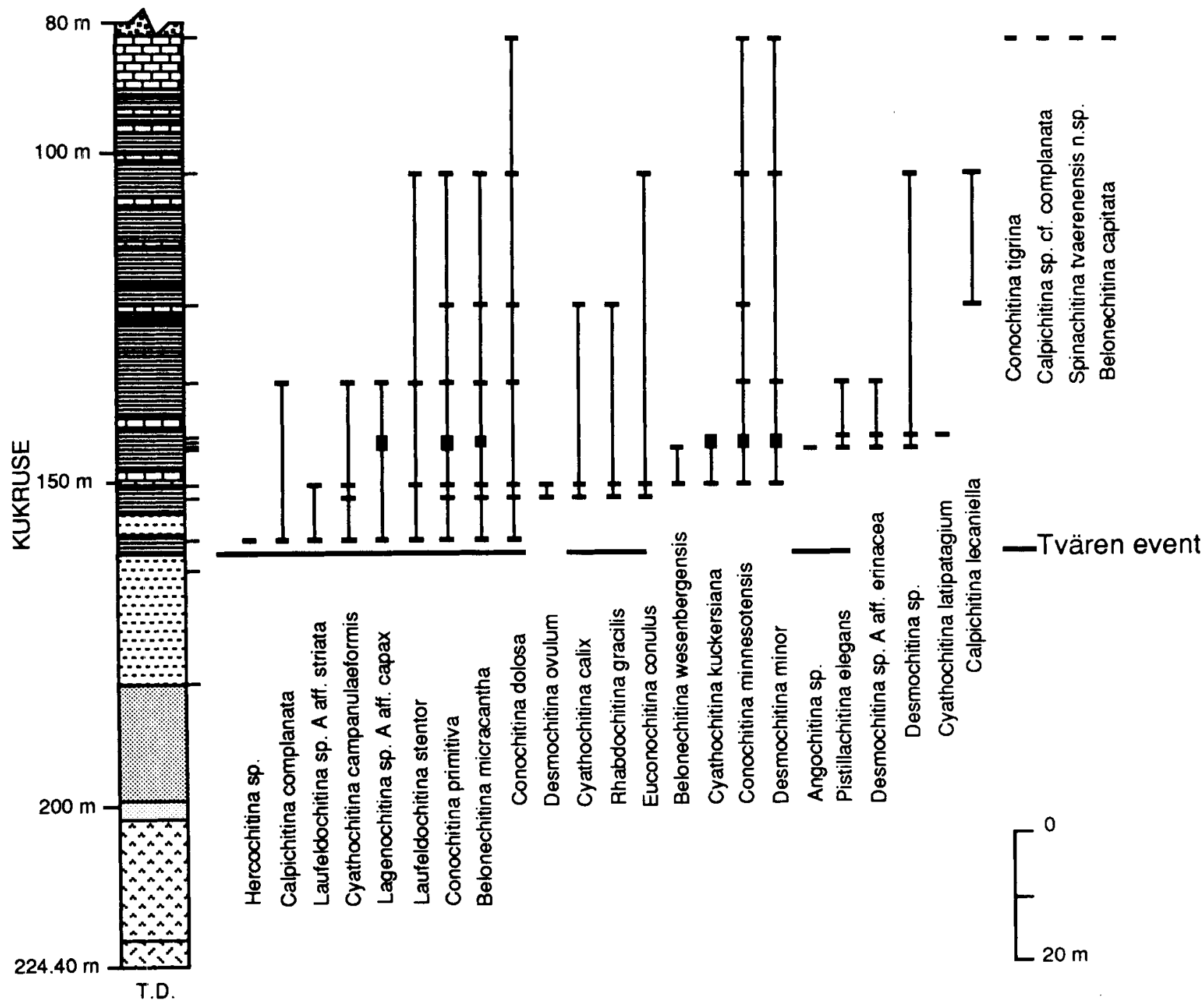

Fig. 6. Faunal log of the Tvären 2 borehole, Tvären crater.

\section{Kärdla crater}

The Kärdla crater is situated in the subsurface, just east of the Kardla city, and on the north coast of the Island of Hiiumaa. It has been discussed by Puura \& Suuroja (1992) and Grahn \& Nolvak (1993). The chitinozoan biostratigraphy in two boreholes drilled in the structure has been investigated. Palukiila 383 (Fig. 8) is situated within the crater near the northeastern rim, and Männamaa (Fig. 9) about $20 \mathrm{~km}$ southwest of the crater (Fig. 7). The Paluküla 383 borehole terminated just above the first post-impact sediments, which consist of calcareous mudstone with rare limestone intercalations. However, ejecta from the impact are spread over large areas in northwest Estonia. They consist of a quartz-rich limestone, known as the Kisuvere Member of the lower Tatruse Formation (Pōlma et al. 1988). This layer is present at $164.82-164.93 \mathrm{~m}$ and has been dated in the Männamaa borehole. It gives a precise dating of the first post-impact sedimentation in the crater, as well as the impact event (Grahn \& Nõlvak, 1993). In both the Paluküla 383 and Männamaa boreholes Lagenochitina sp. A aff. capax and Spinachitina multiradiata appear above the first occurrence of the index species Lagenochitina dalbyensis. This suggests that the impact event cannot be much younger than the middle part of the $L$. dalbyensis Zone, since $S$. multiradiata has its first occurrence in the middle part of this zone. In the Männamaa borehole the Kisuvere Member is situated above the last occurrence of Angochitina curvata, and before the first occurrence of $L$. dalbyensis, which means that the impact event, and the first post-impact sedimentation, took place in the early Caradoc and corresponds to the transition between the chitinozoan Zones of $A$. carvata and $L$. dalbyensis (Grahn \& Nõlvak, 1993; Nõlvak \& Grahn 1993; Fig. 14). 

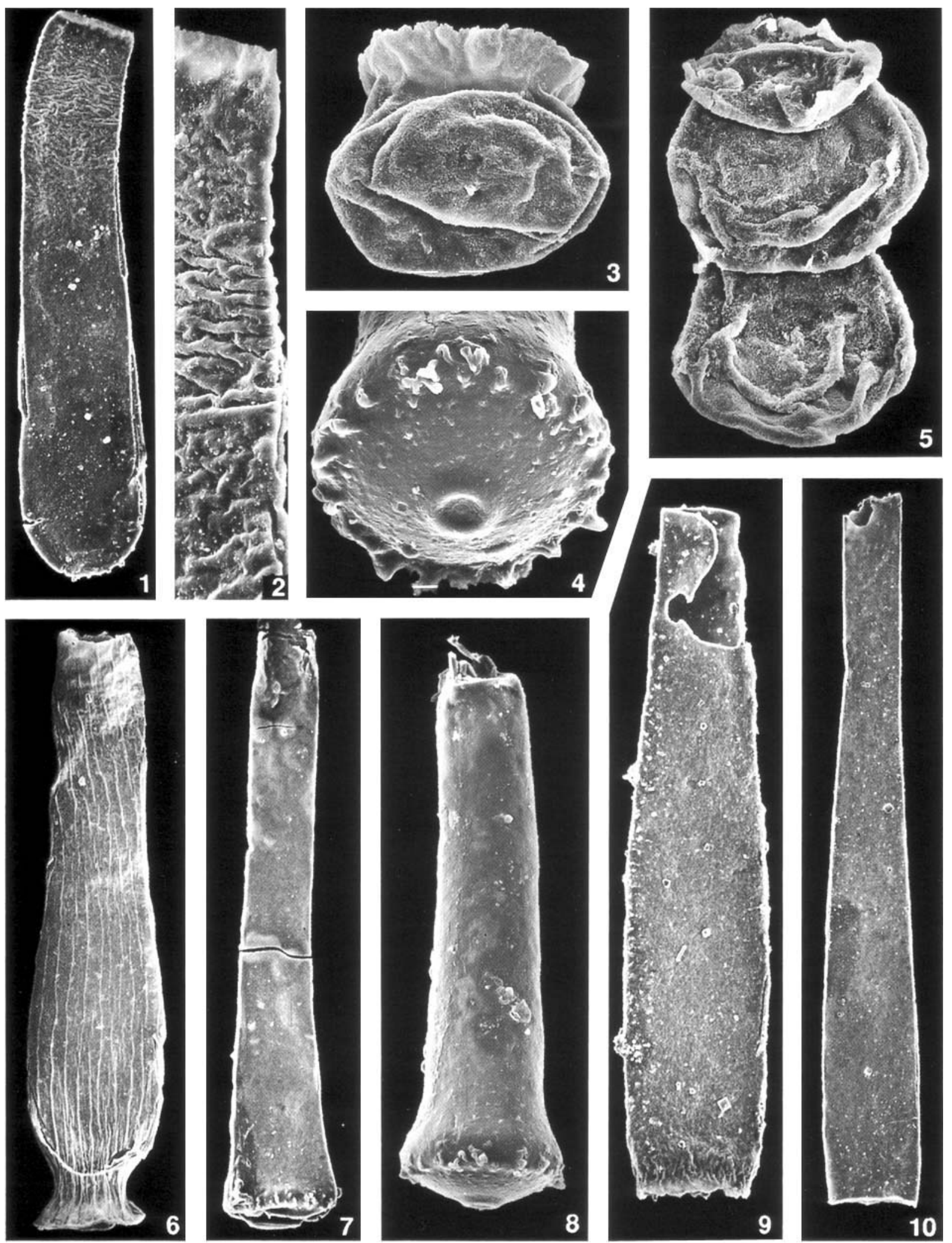

Plate 2 


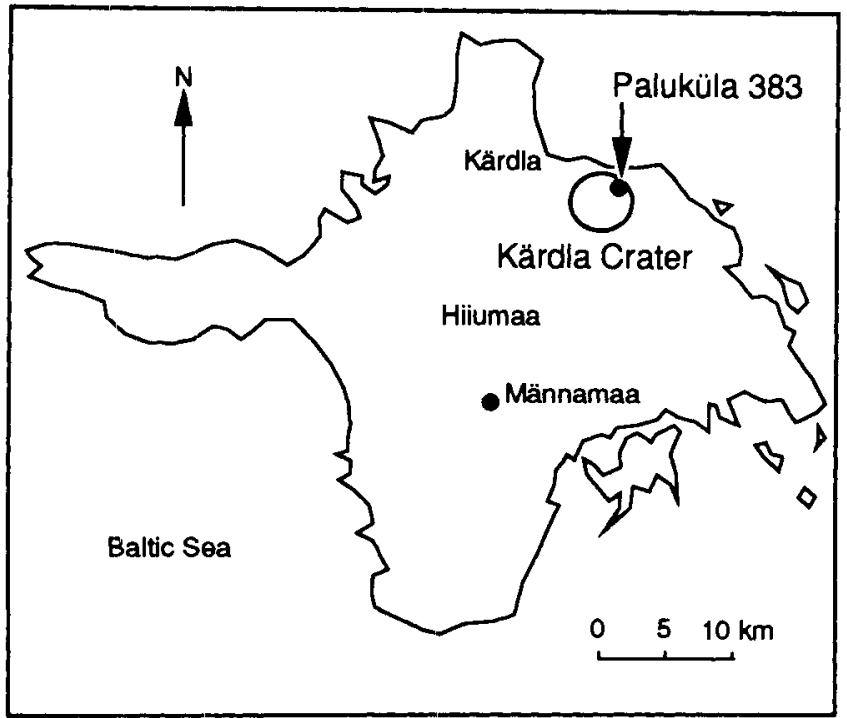

Fig. 7. Map showing the sites of the investigated boreholes in connection with the Kärdla crater, Hiiumaa, Estonia

\section{Lockne crater}

The Lockne crater is situated at Lake Lockne, about $20 \mathrm{~km}$ southeast of the town of Östersund in the province of Jämtland. The crater has been described by Simon (1987), Lindström \& Sturkell (1992) and Grahn \& Nõlvak (1993). Three sections outside the west rim of the crater were investigated southwest of the village of Tandsbyn (Fig. 10). The first section, described by Thorslund (1940, fig. 21), is a railway-cut at Lappgrubban about $1.1 \mathrm{~km}$ southwest of the Tandsbyn church (Fig. 11). The second section is along the stream Ynntjärnsbäcken, about $400 \mathrm{~m}$ east of Lake Ynntjärn (Fig. 12), and the third section is a railway-cut, described by Simon (1987; Fig. 23), situated about $400 \mathrm{~m}$ west of Lake Ynntjärn (Fig. 13). All three localities exhibit the sandy resurge deposit locally known as 'Loftarstone', which is followed upwards by the first post-impact sediments, a limestone with interbedded calcareous shales. Locally the limestone contains patch reefs that grew on the crater rim. Characteristic of the chitinozoan fauna is the presence of the index species Lagenochitina dalbyensis (Pl. 3, fig. 3) together with Lagenochitina sp. A aff. capax in two of the localities (Lappgrubban and Ynntjärnsbäcken). This means that the Lockne event (Grahn \& Nõlvak, 1993), and the first post-impact sedimentation in the crater, took place in the early Caradoc, and correspond to the lower part of the $L$. dalbyensis chitinozoan Zone. The Lockne event may be coeval with the Kärdla event, but most probably is slightly younger. The occurrence of Belonechitina hirsuta in the section at Ynntjärnsbäcken (Fig. 12) suggests that beds younger than those corresponding to the $L$. dalbyensis Zone are also present at this locality. Other chitinozoan species present are, for instance Cyathochitina campanulaeformis characteristic of the earliest Caradoc, Calpichitina lecaniella, Desmochitina ovulum, and Belonechitina capitata (P1. 3, fig. 10). It should be noted that one boulder from the impact-related coarse breccia at Ynntjärnsbäcken yielded a chitinozoan assemblage from the upper? part of the Kukruse Stage (Zone of Laufeldochitina stentor, i.e. Laufeldochitina stentor, Conochitina primitiva, $C$. cf. minnesotensis, Belonechitina capitata, Desmochitina erinacea, and D. minor). Previously beds of this age had not been reported from the autochthon in Jämtland (Jaanusson \& Karis 1982, fig. 1).

\section{CONCLUSION}

The immediate appearance of chitinozoans in the craters after the impact events, and their rapid evolution, have made it possible to achieve a high-resolution biostratigraphy of virtually complete sequences related to the impact craters. The planktic nature of the chitinozoophorans (Grahn, 1981) may also make it possible to date other types of natural hazards in marine environments (e.g. volcanic eruptions, earthquakes, etc.), from Ordovician through Devonian, sometimes with a precision of less than one million years. Chitinozoans occur in most lithologies, except for coarse sandstones, reef limestones, carbonate mounds and also marine redbeds and dolomites.

The environments within the craters were restricted. The first Ordovician reefs known from Baltoscandia started to grow on the rim of the Lockne crater during early Caradoc (lower Idavere Stage) times (Fig. 14). The climate was obviously warm enough for the formation of reefs, and the absence of other contemporary reefs in Baltoscandia indicates that the seas were probably deeper (Lindström 1971) than generally believed earlier. (For a summary see Jaanusson, 1982.)

\section{Explanation of Plate 2}

Selected chitinozoans from the Tvären crater. Early Caradoc. Fig. 1. Conochitina tigrina Laufeld, 1967. Tvären 2 borehole, core sample at $82.15 \mathrm{~m}$. Specimen in lateral view, SEM $\times 150$. IGR 58646 (Q. 36). Fig. 2. Conochitina tigrina Laufeld, 1967. Same specimen as in fig. 1. Detail showing the corrugations on the neck, SEM $\times 750$. Fig. 3. Calpichitina lecaniella (Eisenack, 1965). Tvären 2 borehole, core sample at 123.02-123.05 m. Specimen in lateral view, SEM $\times 500$. IGR 58643 (M. 36/1). Fig. 4. Spinachitina tvaerenensis sp. nov. Holotype. Tvären 2 borehole, core sample at $82.15 \mathrm{~m}$. Detail of the base showing the processes. Note the mucron, SEM $\times 600$. Fig. 5. Calpichitina lecaniella (Eiscnack, 1965). Tvären 2 borehole, core sample at $123.02-123.05 \mathrm{~m}$. Chain with two specimens in lateral view, SEM $\times 500$. IGR 58643 (L. 39/4). Fig. 6. Laufeldochitina stentor (Eisenack, 1937). Tvären 2 borehole, core sample at $102.97 \mathrm{~m}$. Specimen in lateral view, SEM $\times 100$. IGR 58644 (Q. 40). Fig. 7. Spinachitina tvaerenensis sp. nov. Tvären 2 borehole, core sample at $82.15 \mathrm{~m}$. Specimen in lateral view, SEM $\times 200$. IGR 58645 (R. 38/3). Fig. 8. Spinachitina tvaerenensis sp. nov. Holotype. Tvären 2 borehole, core sample at $82.15 \mathrm{~m}$. Specimen in lateral view, SEM $\times 350$. IGR 58645 (R. 40). Fig. 9. Laufeldochitina sp. A aff. striata. Tvären 2 borehole, core sample at $158.77-158.80 \mathrm{~m}$. Specimen in lateral view, SEM $\times 200$. IGR 58634 (R. 37/2). Fig. 10. Laufeldochitina sp. A aff. striata. Tvären 2 borehole, core sample at 150.78-150.81 m. Specimen in lateral view, SEM $\times 100$. IGR 58636 (S. 41/1). 


\section{PALUKÜLA 383}

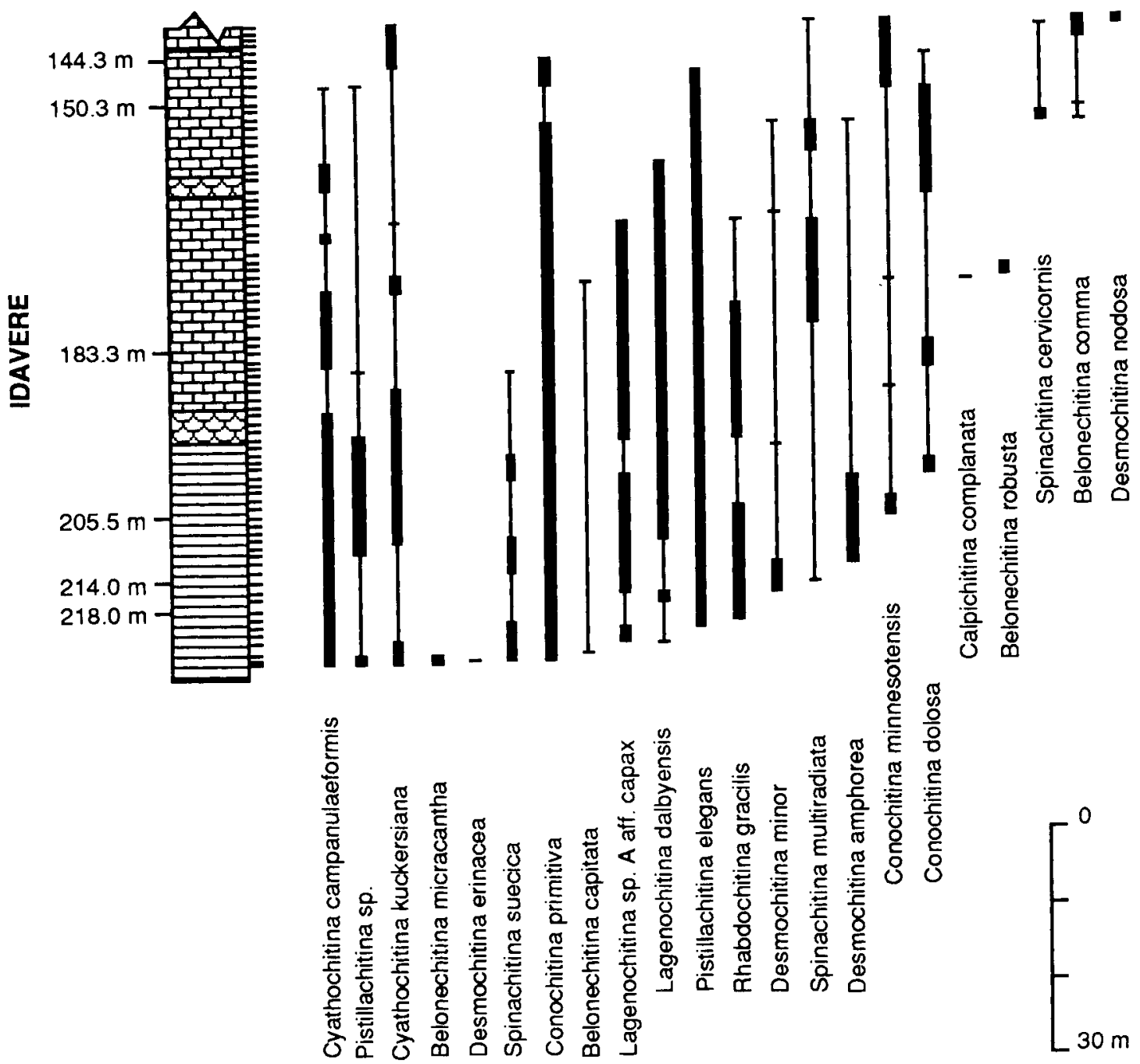

Fig. 8. Faunal $\log$ of the Paluküla 383 borehole, Kärdla crater. The depths on the left side of the column indicate the levels of discontinuity surfaces.

\section{SYSTEMATIC DESCRIPTIONS}

\section{Cyathochitina hunderumensis sp. nov.}

(Pl. 1, figs 1, 10, 11)

?1967 Cyathochitina campanulaeformis Eisenack; Jenkins: 456-458, pl. 71, figs 8-11.

1976 Cyathochitina campanulaeformis Eisenack: 187, pl. 2, fig. 4

1980 Cyathochitina cf. campanulaeformis Eisenack; Grahn: 25-27, pl. 15, figs A-D.

1984 Cyathochitina campanulaeformis Eisenack; Grahn: $16-17$.

Derivation of name. Latin, hunderumensis, from the late Arenig substage of Hunderum where the species is common.

Diagnosis. Small Cyathochitina with a short thickened carina and a basal scar on the apex of the vesicle.
Holotype. Pl. 1, fig.1. IGR 58614 (L. 39/4).

Type locality. Fylla 3 borehole, core sample at $254.30 \mathrm{~m}$, Granby crater, Östergötland, south Sweden.

Description. A small species of Cyathochitina. Vesicle smooth with a characteristic bell-like to conical shape. The maximum width is at the margin. The margin is provided with a short thickened carina. A basal scar is present. The neck is cylindrical, and shorter than half the total length. Aperture straight.

Dimensions. The dimensions given by Grahn (1980, p. 27) are characteristic also for the specimens from the Granby crater. He noted that also the main parts of the populations fall within the length:width ratio $1.25-2: 1$. From the type level 30 flattened specimens were measured. A coefficient of 0.7 was used to restore the diameter of chamber and neck. The total length is $156-280 \mu \mathrm{m}$ (holotype $233 \mu \mathrm{m}$, mean value $199 \mu \mathrm{m}$ ), 


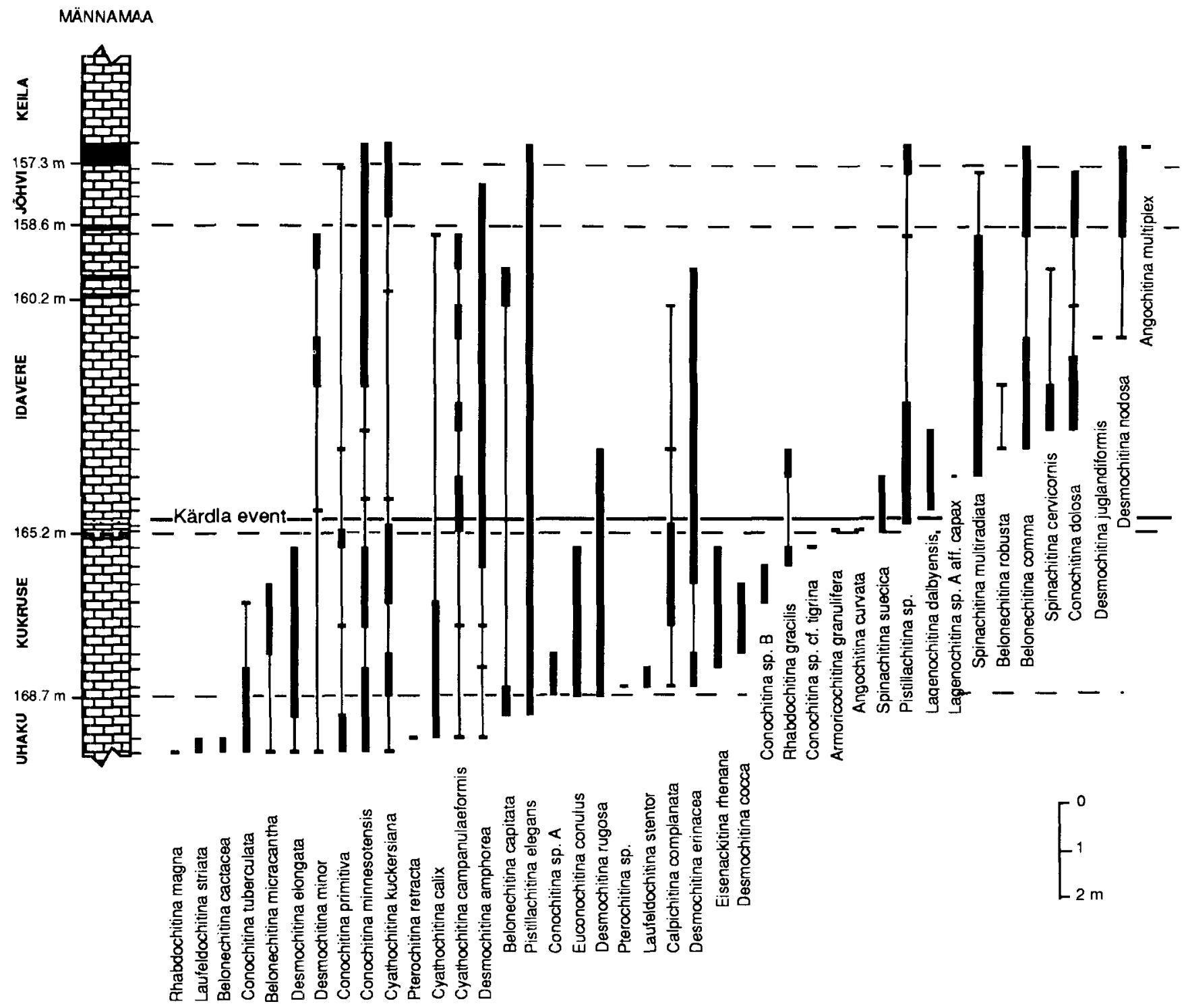

Fig. 9. Faunal log of the Mânnamaa borchole, Kärdla crater. The depths on the left side of the column indicate the levels of discontinuity surfaces.

maximum width $73-124 \mu \mathrm{m}$ (holotype $123 \mu \mathrm{m}$, mean value $94 \mu \mathrm{m}$ ), width of neck $42-53 \mu \mathrm{m}$ (holotype $48 \mu \mathrm{m}$, mean value $47 \mu \mathrm{m}$ ) and the length of the neck $50-94 \mu \mathrm{m}$, (holotype $90 \mu \mathrm{m}$, mean value $70 \mu \mathrm{m}$ ). The ratio of vesicle length/chamber diameter for specimens from the type level is shown in Fig. 15, and the ratio of chamber diameter/neck diameter in Fig. 16.

Discussion. The small $C$. hunderumensis sp. nov, are easily distinguished from typical specimens of Cyathochitina campanulaeformis as defined by Eisenack (1931, 1962) through its small size, and because of the short and thickened carina. Cyathochitina varennensis Paris 1981, from the early Llanvirnian of western France, has a similar size. However, the ratio of length of the neck/length of the vesicle is significantly different.
Occurrence. Cyathochitina hunderumensis sp. nov. ranges from the upper Volkhov Stage (chitinozoan Zone of Conochitina cucumis Nolvak \& Grahn, 1993) to the top of Kunda Stage (upper Arenig-lower Llanvirn). The species is known from Oland (Eisenack, 1976; Grahn, 1980) and Närke (Grahn, unpublished data), Sweden and from the Granby crater (this paper). It occurs also in North Estonia (reported but not illustrated from the Suhkrumägi section in Tallinn by Grahn 1984 as Cyathochitina campanulaeformis). It should be noted that specimens assignated to Cyathochitina campanulaeformis first occur in the Aseri Stage, after the last occurrence of $C$. hunderumensis sp. nov. Specimens similar to $C$. hunderumensis sp. nov. have been reported from the lower Hope Shales (early Llanvirn) in Shropshire, England (Jenkins, 1967). 


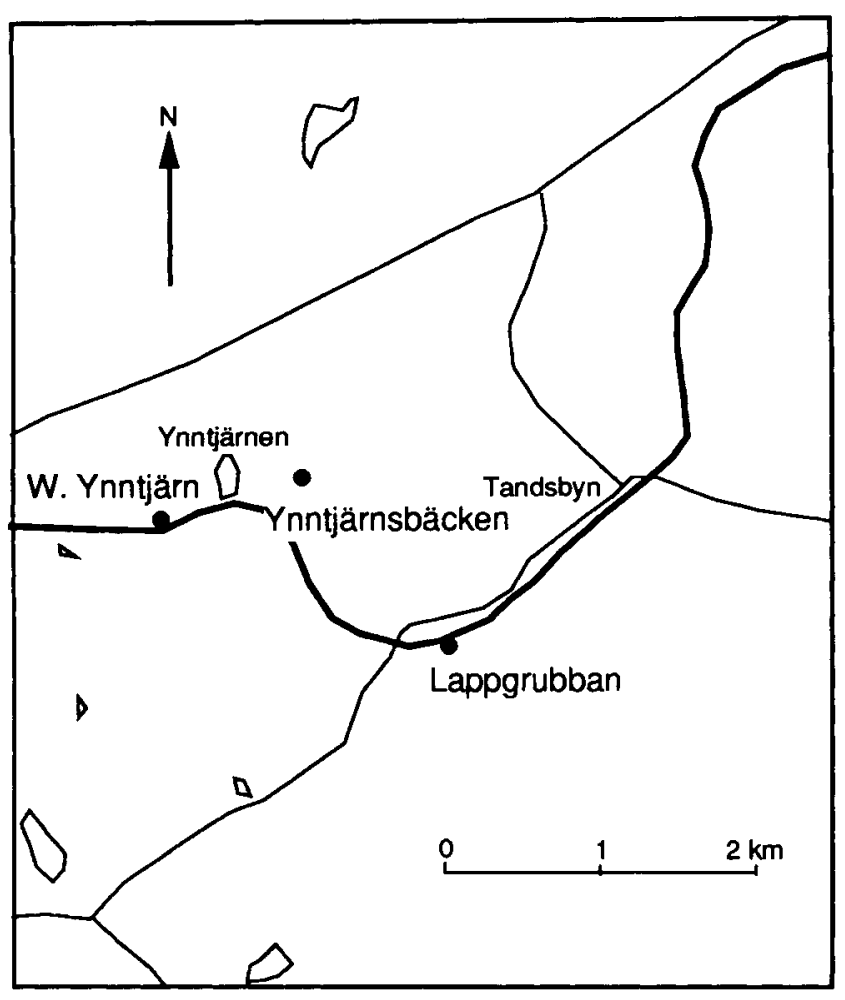

Fig. 10. Map showing the sites of the outcrop localities in connection with the Lockne crater, Jämtland, Sweden.

\section{Spinachitina tvaerenensis sp. nov.}

(Pl. 2, figs 4, 7, 8; Pl. 3, fig. 6, 11)

? 1986 Coronochitina sp. Männil, fig. 2.1.1.

Derivation of name. Latin, tvaerenensis, from Tvären, the type locality for the species.

Diagnosis. Elongated conical species of Spinachitina with a convex base provided with mucron. Crown with about 20 thick processes at the margin.

Holotype. Pl. 2, figs 4, 8. IGR 58645 (R 40).

Type locality. Tvären 2 borehole, core sample at $82.15 \mathrm{~m}$, Tvären crater, Södermanland, south Sweden.

Description. This elongated conical Spinachitina species is characterized by the conical expansion of the chamber

\section{LAPPGRUBBAN}

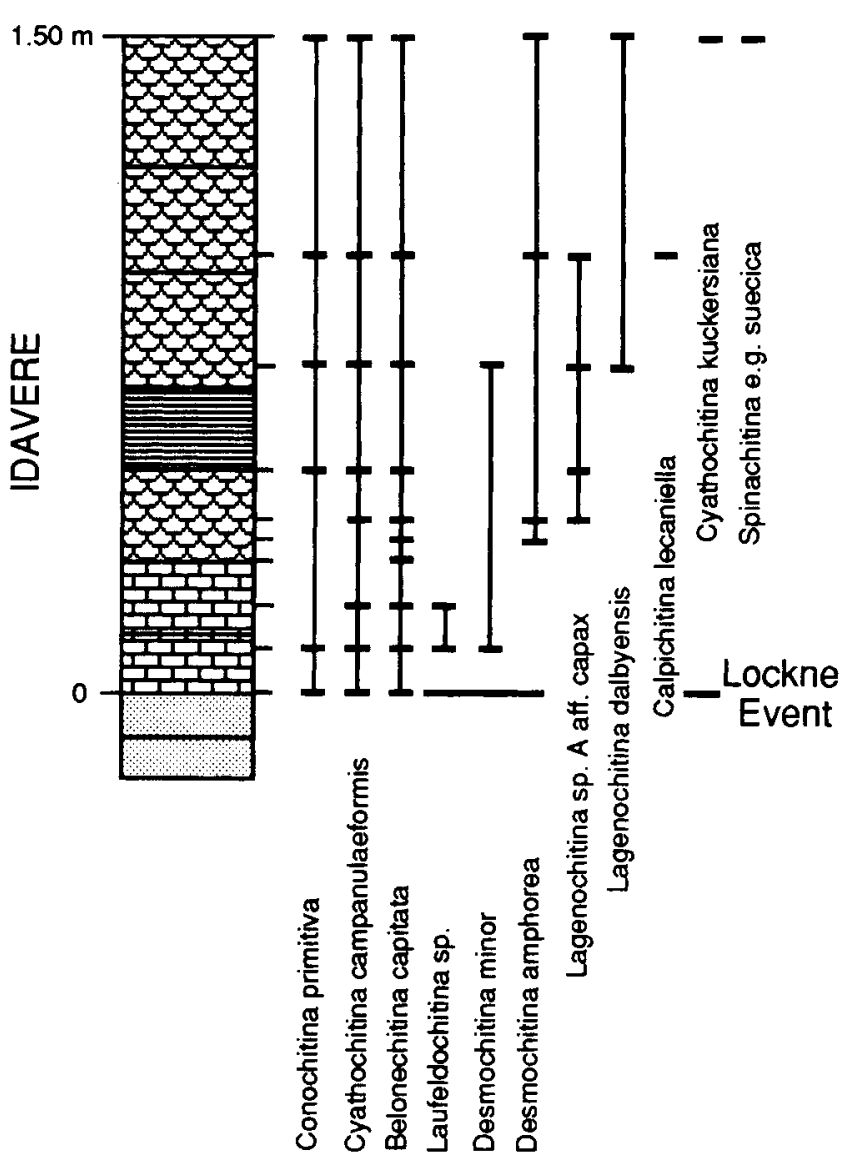

Fig. 11. Faunal log of the Lappgrubban outcrop section, Lockne crater.

close to the margin. The neck is cylindrical and indistinct with a straight aperture. Flexure and shoulder absent. The greatest width is at the margin, which is provided with about 20 robust short and simple conical processes, elongated parallel to the vesicle axis with their proximal end (insertion zone). A mucron is present. The vesicle wall is smooth aperturewards the margin.

\section{Explanation of Plate 3}

Selected chitinozoans from the Granby (Late Arenig), Tvären (Early Caradoc) and Lockne (Early Caradoc) craters. Fig. 1. Lagenochitina sp. A aff. capax. Tvären 2 borehole, core sample at $144.99-145.00 \mathrm{~m}$. Specimen in lateral view, SEM $\times 500$. IGR 58637 (L. $32 / 4)$. Fig. 2. Lagenochitina sp. A aff. capax. Tvären 2 borehole, core sample at $144.99-145.00 \mathrm{~m}$. Specimen in lateral view, SEM $\times 500$. IGR 58637 (P. $35 / 3)$. Fig. 3. Lagenochitina dalbyensis (Laufeld, 1967). Ynntjärnsbäcken, basal $7 \mathrm{~cm}$ of the upper Dalby Limestone. Specimen in lateral view, SEM $\times$ 300. IGR 58632 (L. 37/3). Fig. 4. Conochitina tigrina Laufeld, 1967. Tvären 2 borehole, core sample at $82.15 \mathrm{~m}$. Specimen in lateral view, SEM $\times 200$. IGR 58646 (R. 38/1). Fig. 5. Conochitina sp. 1. Fylla 3 borehole, core sample at $258.00 \mathrm{~m}$. Specimen in lateral view, SEM $\times 350$. IGR 58610 (Q. 38). Fig. 6. Spinachitina tvaerenensis sp. nov. Tvären 2 borehole, core sample at $82.15 \mathrm{~m}$. Detail of the basal part showing the processes, SEM $\times 350$. IGR 58646 (O. 34/3). Fig. 7. Conochitina minnesotensis (Stauffer, 1933). Tvären 2 borehole, core sample at $144.40 \mathrm{~m}$. Specimen in lateral view, SEM $\times 150$. IGR 58639 (N. 45/2). Fig. 8. Rhabdochitina gracilis Eisenack, 1962. Fylla 3 borehole, core sample at $258.00 \mathrm{~m}$. Specimen in lateral view, SEM $\times 100$. IGR 58610 (O. 38). Fig. 9. Lagenochitina esthonica Eisenack, 1955. Fylla 3 borehole, core sample at $254.30 \mathrm{~m}$. Specimen in lateral view, SEM $\times 80$. IGR 58614 (L. 40/3). Fig. 10. Belonechitina capitata (Eisenack, 1962). West Ynntjärn, basal $10 \mathrm{~cm}$ of the upper Dalby Limestone. Specimen in lateral view, SEM $\times 300$. IGR 58622 (M. 36). Fig. 11. Spinachitina tvaerenensis? sp. nov. Tvären 2 borehole, core sample at $82.15 \mathrm{~m}$. Specimen in lateral view, SEM $\times 300$. IGR 58646 (O. $37 / 3)$. 

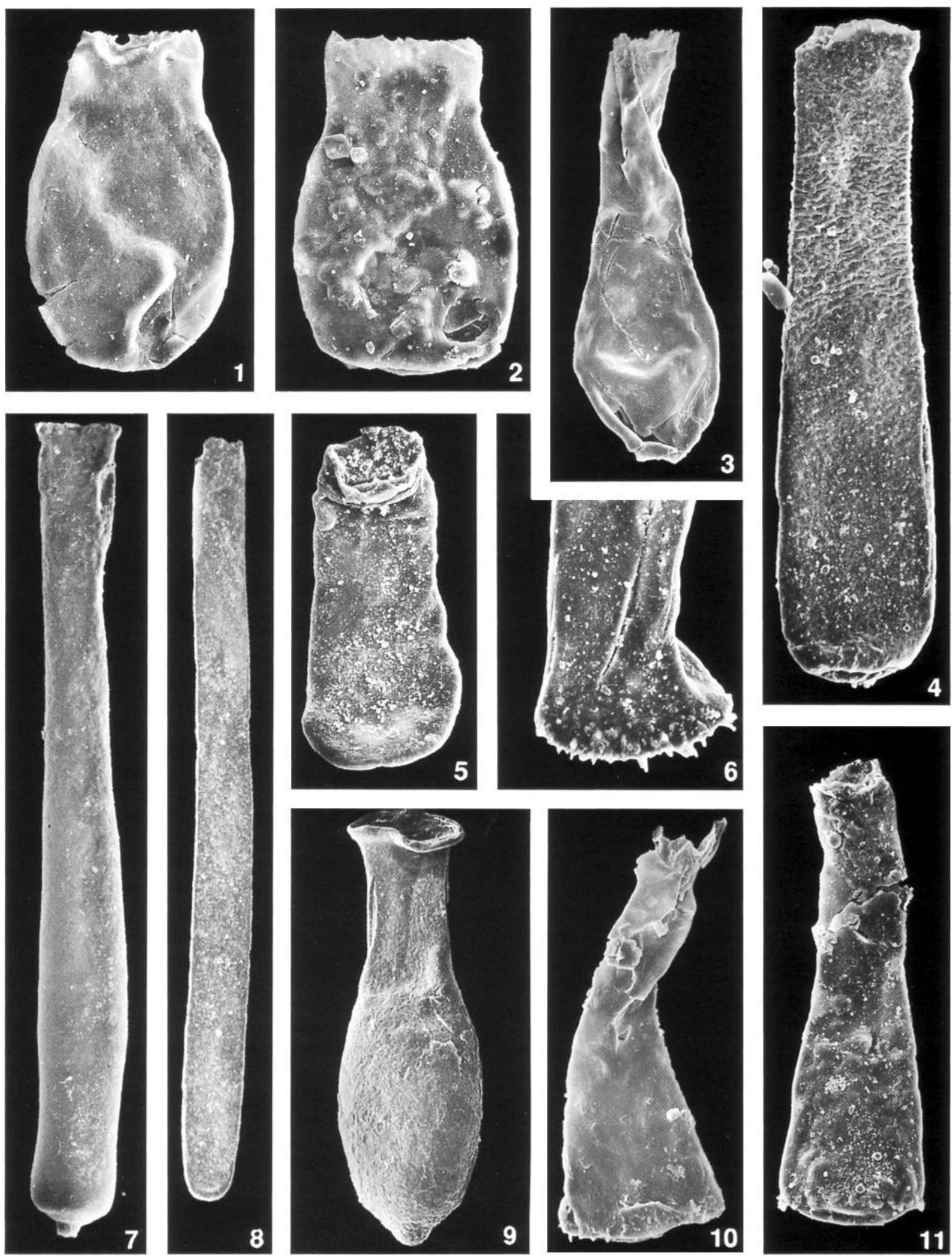

Plate 3 


\section{YNNTJÄRNSBÄCKEN}

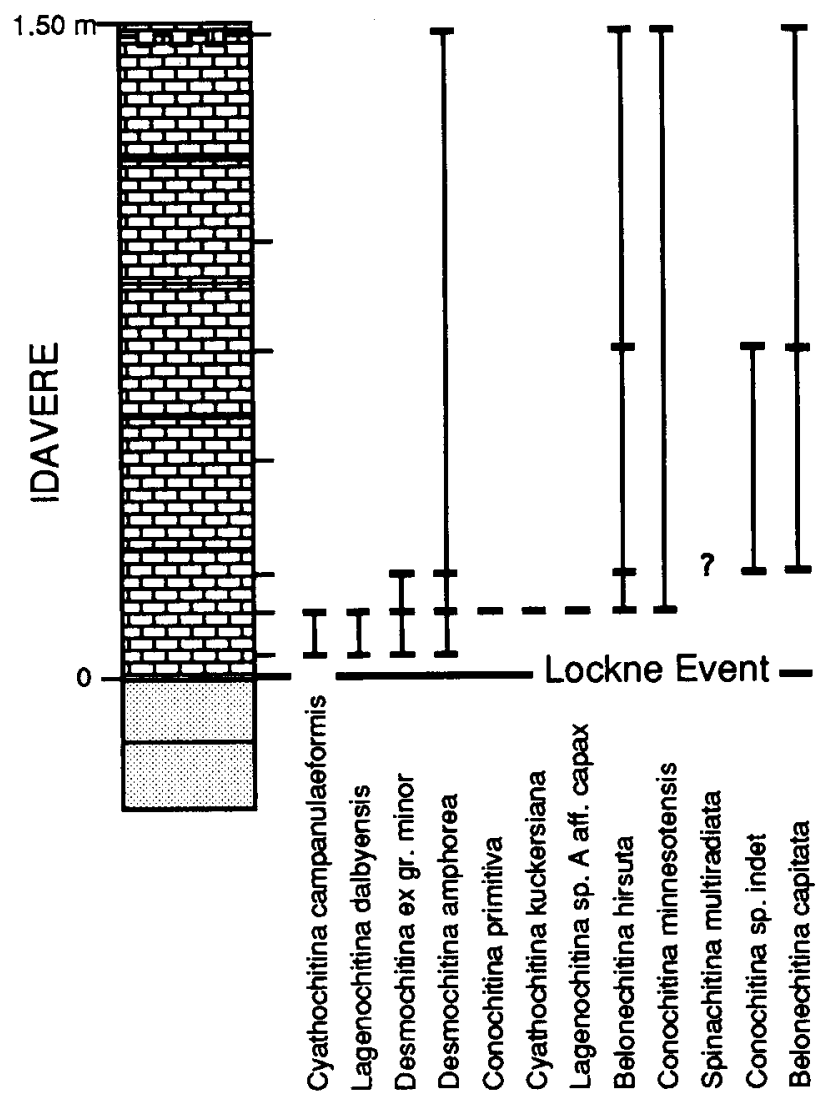

Fig. 12. Faunal log of the Ynntjärnsbäcken outcrop section, Lockne crater.

Corrected dimensions. $(7$ specimens, flattening corrected by a coefficient of 0.7.) Total length $247-568 \mu \mathrm{m}$ (holotype $>257 \mu \mathrm{m}$, broken neck), max width $73-117 \mu \mathrm{m}$ (holotype $76 \mu \mathrm{m}$ ), aperture $41-78 \mu \mathrm{m}$ (holotype, width of neck $43 \mu \mathrm{m}$ ), spines about $7 \mu \mathrm{m}$ (holotype $7 \mu \mathrm{m}$ ).

Occurrence. Spinachitina tvaerenensis $\mathrm{sp}$. nov. has a restricted range in the uppermost Kukruse Stage. It probably corresponds to Coronochitina sp. by Männil (1986), who indicated a range from uppermost Kukruse to lowermost Idavere Stage, where it disappears before the first occurrence of the index species for the chitinozoan Zone of Armoricochitina granulifera Nơlvak \& Grahn 1993 (Cyathochitina cf. reticulifera by Männil, 1986) in the lowermost Idavere Stage.

Tanuchitina granbyensis sp. nov.

(Pl. 1, figs. 2-5)

V. ? 1981 Tanuchitina sp. aff. achabae Paris: 216-217, pl. 40 , figs 14,15 .

Derivation of name. Latin, granbyensis, from Granby, the type locality for the species.

Diagnosis. A long subcylindrical species of Tanuchitina with its carina erected on an ovoid base.
W. YNNTJÄRN

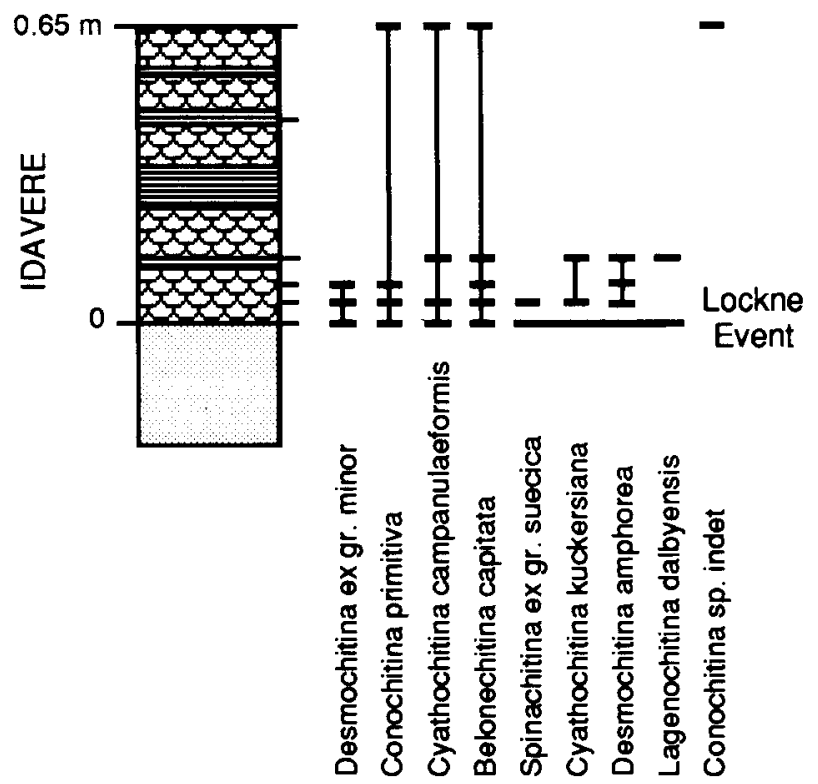

Fig. 13. Faunal log of the outcrop section west of Ynntjärn, Lockne crater.

Holotype. Pl. 1, figs 2, 3. IGR 58601 (D 43).

Type locality. Fylla 9 borehole, core sample at $272.20 \mathrm{~m}$, Granby crater, Östergötland, south Sweden.

Description. A very long slender, almost cylindrical Tanuchitina with a smooth vesicle. Aperture straight. Greatest width about one quarter aperturewards from the ovoid base. Fairly long membranaceous carina surrounding the apex.

Corrected dimensions. (27 specimens, flattening corrected by a coefficient of 0.7.) Total length $>672-1533 \mu \mathrm{m}$ (holotype $1466 \mu \mathrm{m}$, mean value $1262 \mu \mathrm{m}$ ), max. width 82-138 $\mu \mathrm{m}$ (holotype $117 \mu \mathrm{m}$, mean value $97 \mu \mathrm{m}$ ), aperture $60-118 \mu \mathrm{m}$ (holotype $85 \mu \mathrm{m}$, mean value $71 \mu \mathrm{m}$ ), and carina 16-34 $\mu \mathrm{m}$ (holotype $30 \mu \mathrm{m}$ ). The ratio vesicle length/chamber diameter for specimens from the type level is shown in Fig. 17.

Discussion. The length of this species makes it easily distinguishable from any other early Ordovician Tanuchitina species described to date. Tanuchitina achabae from the middle Arenig of western France (Paris, 1981) is half the size in terms of vesicle length. Tanuchitina sp. aff. achabae from the late Arenig of western France is probably a synonym to $T$. granbyensis sp. nov. They are of a similar length and the vesicle is frequently curved along its longitudinal axis. T. granbyensis sp. nov. may be confused with Rhabdochitina gracilis Eisenack when the carina is strongly eroded. The latter is also commonly curved along the long axis of the vesicle.

Occurrence. Tanuchitina granbyensis sp. nov. has so far only been found in late Arenig strata in the Granby crater, Östergötland, south Sweden. It is probably present 


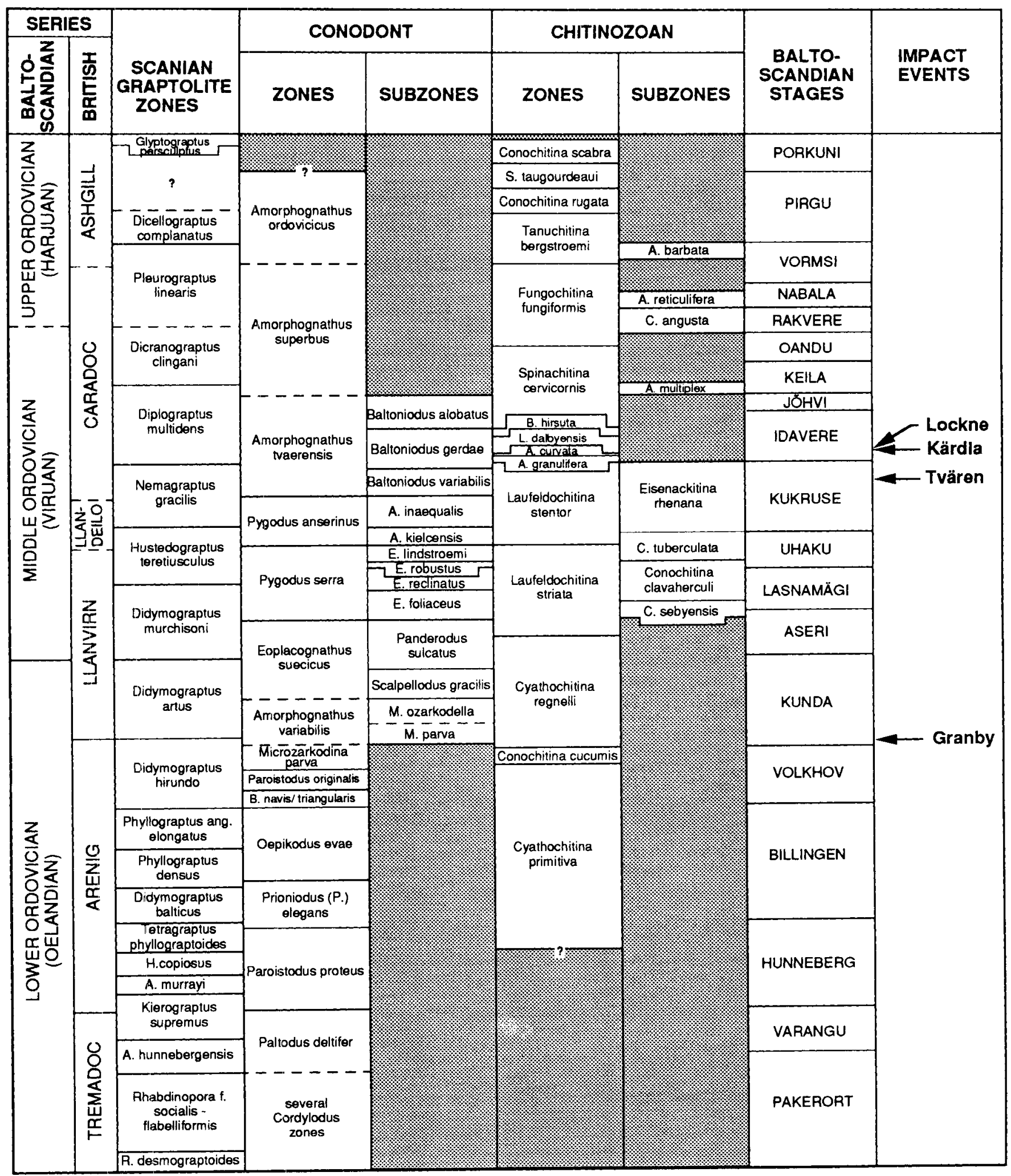

Fig. 14. Correlation table for the impact craters in the Ordovician of Baltoscandia. 


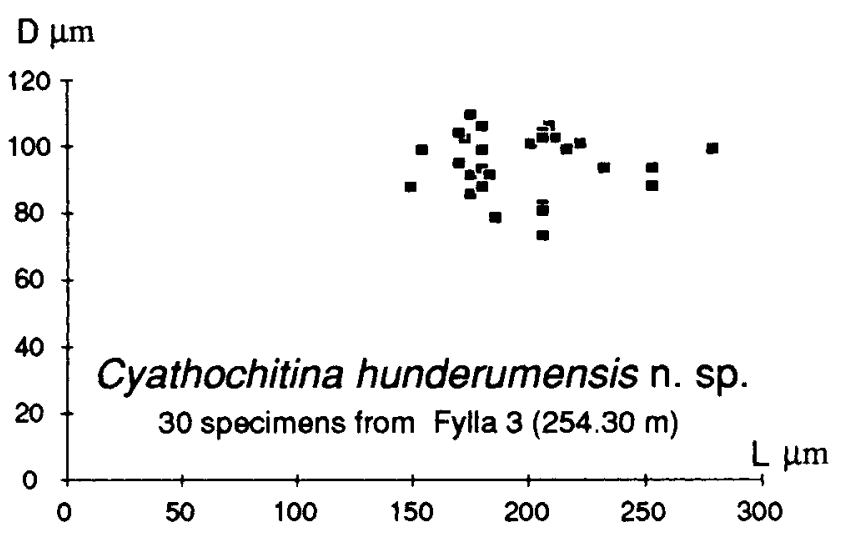

Fig. 15. Diagram showing the vesicle length (L) with regard to the diamcter of the chamber (D) for Cyathochitina hunderumensis $\mathrm{sp}$. nov. (30 flattened specimens measured from the type level, flattening restored with a coefficient of 0.7 .)

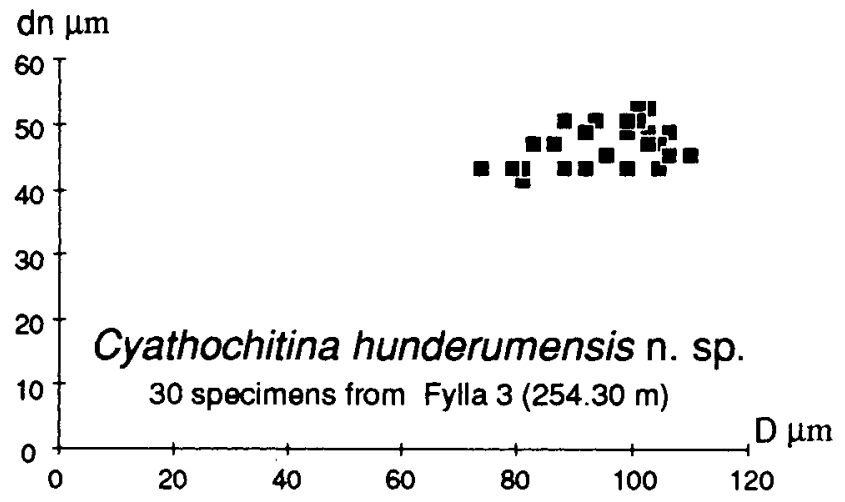

Fig. 16. Diagram showing the chamber diameter (D) with regard to the diameter of the neck $(\mathrm{dn})$ for Cyathochitina hunderumensis sp. nov. (30 flattened specimens measured from the type level, flattening restored with a coefficient of 0.7.)

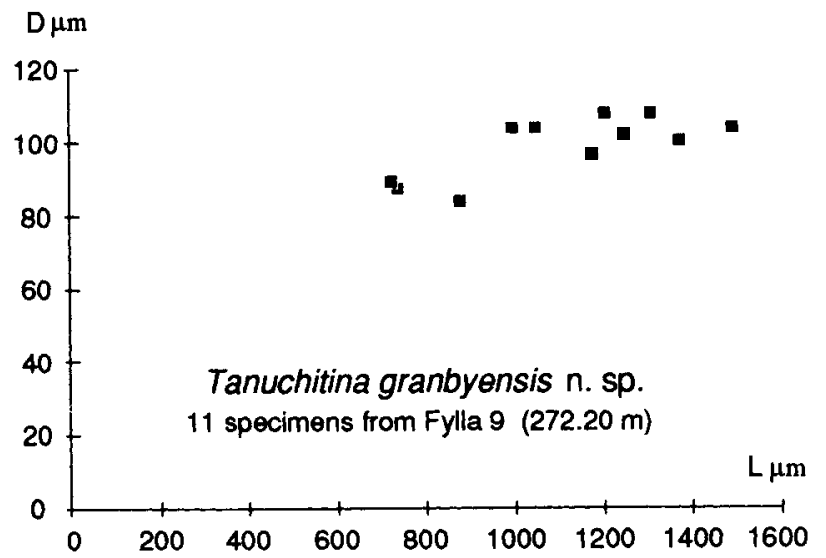

Fig. 17. Diagram showing the vesicle length (L) with regard to the diameter of the chamber (D) for Tanuchitina granbyensis sp. nov. (11 flattened specimens measured from the type level, flattening restored with a coefficient of 0.7 .) in the late Arenig in the lowermost Pissot Formation in western France.

\section{Lagenochitina sp. A aff. capax}

(Pl. 3, figs 1, 2)

Occurrence. Lagenochitina sp. A aff. capax ranges from the upper Kukruse to the lower Idavere Stage. It is a common species in the sequences related to the Tvären, Kärdla and Lockne craters. Its stratigraphical range is concluded from observations in Estonia, as L. sp. A aff. capax is not previously recorded from Sweden.

Remarks. Lagenochitina sp. A aff. capax has great similarities with the holotype of Lagenochitina capax Jenkins 1967 (pl. 73, fig. 3) and with Lagenochitina deunffi Paris 1974. The stratigraphic range is identical (L. capax is slightly younger than $L$. deunffi but they may overlap; Paris 1981), and it cannot be excluded that $L$. sp. A aff. capax is conspecific with one of these species. The size falls completely within the range of Lagenochitina deunffi, but the neck of $L$. deunffi is more narrow than that of $L$. sp. A aff. capax. For a population of 40 flattened specimens (flattening corrected by a coefficient of 0.7 ) from 144.40 and $144.99-145.00 \mathrm{~m}$ the total length is $88-122 \mu \mathrm{m}$ (mean value $103 \mu \mathrm{m}$ ), maximum width 38 $51 \mu \mathrm{m}$ (mean value $44 \mu \mathrm{m}$ ), width of aperture $23-33 \mu \mathrm{m}$ (mean value $30 \mu \mathrm{m}$ ), and length of the neck $13-22 \mu \mathrm{m}$ (mean value $16 \mu \mathrm{m}$ ). The ratio vesicle length/chamber diameter for specimens from level 144.40 and 144.99 $145.00 \mathrm{~m}$ is shown in Fig. 18, and the ratio vesicle length/neck length in Fig. 19.

\section{Laufeldochitina sp. A aff. striata}

(Pl. 2, figs 9, 10)

Occurrence. Laufeldochitina sp. A aff. striata has a short range in the upper Kukruse Stage (corresponding to the middle part of the lower Peetri Member of the Viivikonna Formation) in North Estonia (Laufeldochitina cf. striata by Männil, 1986). Its occurrence in the Tvären 2 borehole is the first safely established in Sweden.

$\mathrm{D} \mu \mathrm{m}$

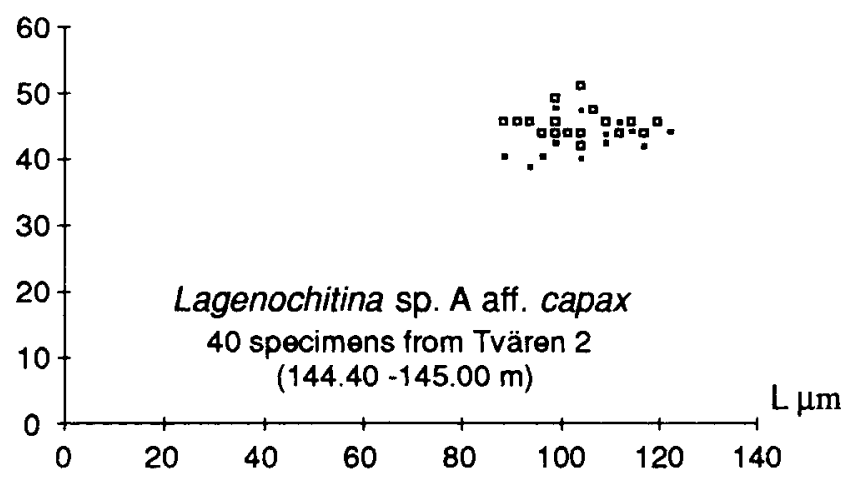

Fig. 18. Diagram showing the vesicle length (L) with regard to the diameter of the chamber (D) for Lagenochitina sp. A aff. capax. (40 flattened specimens measured from levels $144.40 \mathrm{~m}$ (black dot) and $144.99-145.00 \mathrm{~m}$ (squares) in the Tvären 2 borehole, flattening restored with a coefficient of 0.7 .) 


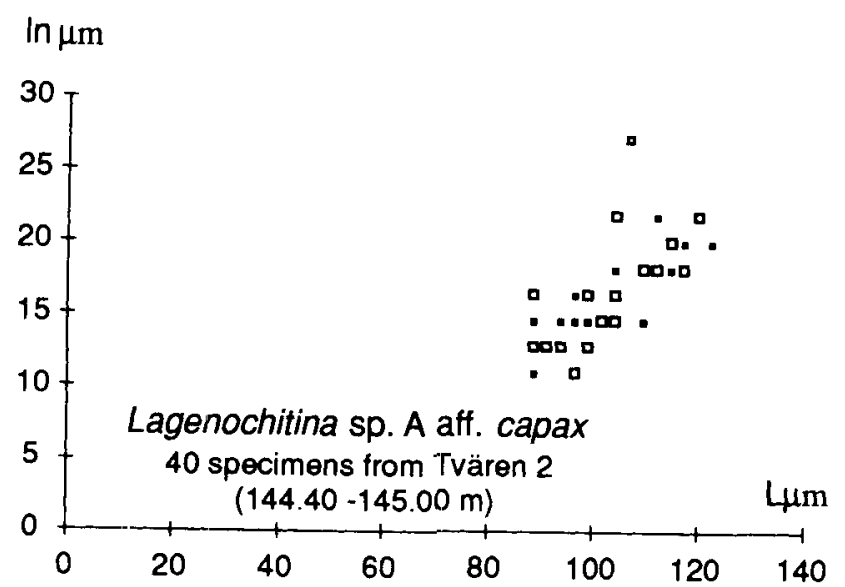

Fig. 19. Diagram showing the vesicle length (L) with regard to the length of the neck (In) for Lagenochitina sp. A aff. capax. (40 flattened specimens measured from levels $144.40 \mathrm{~m}$ (black dot) and $144.99-145.00 \mathrm{~m}$ (squares) in the Tvären 2 borehole, flattening restored with a coefficient of 0.7 .)

Remarks. Characteristic Laufeldochitina sp. A aff. striata differ from Laufeldochitina striata (Eisenack, 1937) in possessing a predominantly smooth wall. A striate ornamentation restricted to the basalmost part may occur on some specimens (PI. 2, fig. 9). The dimensions fall within the range of Laufeldochitina striata.

\section{ACKNOWLEDGEMENTS}

We are indebted to Professors J. Bergström and $M$. Lindström (Stockholm, Sweden), to Professor M. Rubel (Tallinn, Estonia) and Dr. S. Molyneux (Keyworth, Great Britain) for valuable comments on the manuscript. The work of YG has been supported by the Swedish Natural Science Research Council (NFR G-GU 8811-308). Our sincere thanks to all.

\section{Manuscript received April 1994 \\ Manuscript accepted September 1994}

\section{REFERENCES}

Achab, A. 1986. Assemblages de chitinozoaires dans l'Ordovicien inférieur de l'est du Canada. Canadian Iournal of Earth Sciences, 23: $682-695$.

Bockelie, T. G. 1980. Early Ordovician Chitinozoa from Spitsbergen. Palynology, 4: 1-14.

Bruun, Å. \& Dahlman, B. 1982. Granbystrukturen. In Wickman, H., Bruun, А., Dahlman, B. \& Vidal, G. (Eds), Descriptions to the map of solia rocks Hio NO. Serie Af 120: 102-109, Sveriges Geologiska Undersökning, Uppsala.

Combaz, A. \& Peniguel, G. 1972. Élude palynostratigraphique de l'Ordovicien dans quelques sondages du Bassin de Canning (Australie Occidentale). Bulletin du Centre de Recherche de Pau, SNPA 6: $121-167$.

Eisenack, A. 1931. Neue Mikrofossilien des baltischen Silurs. I. Palaeontologische Zeitschrift, 13: 74-118.

Eisenack, A. 1937. Neue Mikrofossilien des baltischen Silurs. IV. Palaeontologische Zeitschrift, 19: 218-243.

Eisenack, A 1962. Neotypen baltischer Silur Chitinozoen und neue Arten. Neues Jahrbuch für Geologie und Paläontologie,
Abhandlungen 114: 291-316.

Eisenack, A. 1976. Mikrofossilien aus dem Vaginatenkalk von Hälludden, Öland. Palaeontographica A 154: 181-203.

Flodén, T., Tunander, P. \& Wickman, F. E. 1986. The Tvären Bay structure, an astrobleme in southeastern Sweden. Geologiska Föreningen i Stockholm Förhandlingar, 108: 225-234.

Grahn, Y. 1980. Early Ordovician Chitinozoa from Öland. Sveriges Geologiska Undersökning, C 775: 1-41.

Grahn, Y. 1981. Ordovician Chitinozoa from the Stora Asbotorp boring in Västergötland, south-central Sweden. Sveriges Geologiska Undersökning Serie, C 787: 1-40.

Grahn, Y. 1984. Ordovician Chitinozoa from Tallinn, northern Estonia. Review of Palaeobotany and Palynology, 43: 5-31.

Grahn, Y. \& Nõlvak, J. 1993. Chitinozoan dating of Ordovician impact events in Sweden and Estonia. A preliminary note. Geologiska Föreningen i Stockholm Förhandlingar, 115: 263-264.

Henkel, H. \& Pesonen, L. J. 1992. Impact craters and craterform structures in Fennoscandia. Tectonophysics, 216: 31-40.

Jaanusson, V. 1982. Introduction to the Ordovician of Sweden. In Bruton, D. L. \& Williams. S. H. (Eds), IV International Symposium on the Ordovician System. Field Excursion Guide. 1-90, Paleontological Contributions from the University of Oslo, 279.

Jaanusson, V. \& Karis, L. 1982. Introduction to the Ordovician in Jämtland. In Bruton, D. L. \& Williams, S. H. (Eds), IV International Symposium on the Ordovician System. 43-46, Field Excursion Guide. Paleontological Contributions from the University of Oslo 279.

Jenkins, W. A. M. 1967. Ordovician Chitinozoa from Shropshire. Palaeontology, 10: 436-488.

Lindström, M. 1971. Vom Anfang, Hochstand und Ende eines epikontinentalmeeres. Geologische Rundschau, 60: 419-438.

Lindström, M. \& Sturkell, F. F. 1992. Geology of the Early Palaeozoic Lockne impact structure, Central Sweden. Tectonophysics, 216: 169-186.

Lindström, M., Flodén, T., Grahn, Y., \& Kathol, B. 1994. Post-impact deposits in Tvären, a marine Middle Ordovician crater south of Stockholm, Sweden. Geological Magazine, 131: 91-103.

Männil, R. 1986. Stratigraphy of kukersite-bearing deposits C1b-C3. In Puura, V. (Ed.), Geology of the Kuckersite-bearing beds of the Baltic oil shale basin. 12-24, Institute of Geology. Estonian Academy of Science, Tallinn. [In Russian.]

Merrill, G. K. 1980. Ordovician conodonts from the Åland Islands, Finland. Geologiska Föreningen i Stockholm Förhandlingar, 101: 329-341. Stockholm.

Nilsson, R. 1983. The Didymograptus hirundo and Akidograptus ascensus Zones of the Lovisefred core, NW Scania, south Sweden. Geologiska Föreningen $i$ Stockholm Förhandlingar, 105: $261-267$.

Nõlvak, J. \& Grahn, Y. 1993. Ordovician chitinozoan zones from Baltoscandia. Review of Palaeobotany and Palynology, 79: 245-269.

Paris, F. 1981. Les Chitinozoaires dans le Paléozoique du Sud-Ouest de l'Europe. Mémoires de la Société géologique et minéralogique de Bretagne, 26: Rennes.

Põlma, L., Sarv, L. \& Hints, L. 1988. Lithology and fauna of the type sections of the Caradoc Series in North Estonia. 1-101, Institute of Geology. Estonian Academy of Sciences, Tallinn.

Puura, V. \& Suuroja, K. 1992. Ordovician impact crater at Kärdla, Hiiumaa Island, Estonia. Tectonophysics, 216: 143-156.

Simon, H. 1987. Stratigraphie, Petrographie und Entstehungsbedingungen von Grobklastika in der autochthonen, ordovizischen Schichtenfolge Jämtlands (Schweden). Sveriges Geologiska Undersökning, C 815: 1-156.

Thorslund, P. 1940. On the Chasmops serics of Jämtland and Södermanland (Tvären). Sveriges Geologiska Undersökning, C 436: $1-191$.

Winterhalter, B. 1982. The bedrock geology of Lumparen Bay, Åland. Geological Survey of Finland. Bulletin, 317: 116-129. 